\title{
Development of Regional Innovation System Model-Based Economic, Science and Technology, Social and Cultural Factors to Improve Regional Competitiveness in Malang East Java Province - The Republic of Indonesia
}

\author{
Harmono \\ Merdeka University Malang; Email: harmonolp2d@gmail.com \\ Nazief Nirwanto \\ Merdeka University Malang; Email: naziefnirwanto@gmail.com
}

Doi:10.5901/mjss.2016.v7n3s1p415

\section{Abstract}

A regional development required orientation multidemensional. As development in Malang Regency based on the orientation of the economy, science and technology, as well as the socio-cultural context. Therefore, this research aims to develop a model "SIDa" or "RIS" (Regional Innovation System) which is oriented multidimensional reality based on the exploration of the condition of the area. The implementation of RIS is to promote the competitiveness of the area based on the dualistic exact sciences and social sciences are usually considered unimportant. Such a collaborative approach is believed to be able to solve the problem and multidimensional social reality. In this research found six dimensions that can be used as a model to build regional competitiveness, namely; (1) Regional Innovation Systems, (2) Mapping the Cultural Zone of Economic and Social Affairs, (3) Industry Cluster, (4) Innovation Linkage, (5) Technology, and (6) Pillar thematic line with regional development programs. The research findings indicate that the build RIS must involve programs are delivered in regional planning system. With this model can be implemented throughout an integrated program in favor of regional competitiveness.

Keywords: competitiveness, social-economic-culture zoning, and Regional Innovation System (RIS)

\section{Background}

Regional competitiveness is conceptually intended to be a development policy strategy by utilizing the advantages of each region. Development developed through planned and integrated program to gain competitive advantage (Kazuhiza, 2005). The competitive advantage is based on the condition of the socio-cultural context-zone economy. Furthermore, supported by basic infrastructure, roads, facility of irrigation, education and health, market development, as well as other public facilities to create value-added products of the main area. However, it must also be supported by the diffusion of technology network system of marketing, human resources and skilled professionals, supply of raw materials potential, related industries, institutional system and government policy (Ministry of Research and Technology, 2012)

The development of the policy development program at this time according to the stated, development policy program orientation President-elect Joko Widodo hinted not to continue expansion and acceleration of the Masterplan program economic development of Indonesia (MP3EI) (The Ministry of Finance of the Republic of Indonesia, 2012; Kompas, 2014). The President convey, there is a difference between the MP3EI orientation and perspectives of development that will be carried out on his administration together with Jusuf Kalla. The orientation is clearly different. i.e., oriented to agriculture, food sovereignty, and the entire infrastructure. The policy will be implemented is to build irrigation systems, farm-produce new agricultural land, fertilizers, subsidy and so on. Responding to the orientation of the development policy is important, but perhaps less so regional councils affected. Especially at the regional level development district/city more basing potential local wisdom (Fatchan, 2004) and oriented on law No. 32 of 2004 concerning regional governments. The most important points in the implementation of the results of the research and development of science technology as well as social engineering must be collaboration and support the program (Malang Regency Regulation No. 2-2011). Schematic components in determining the competitiveness of regions can be seen in Figure 1. 
Mean Indicators for The Determinant of Regional Competitiveness

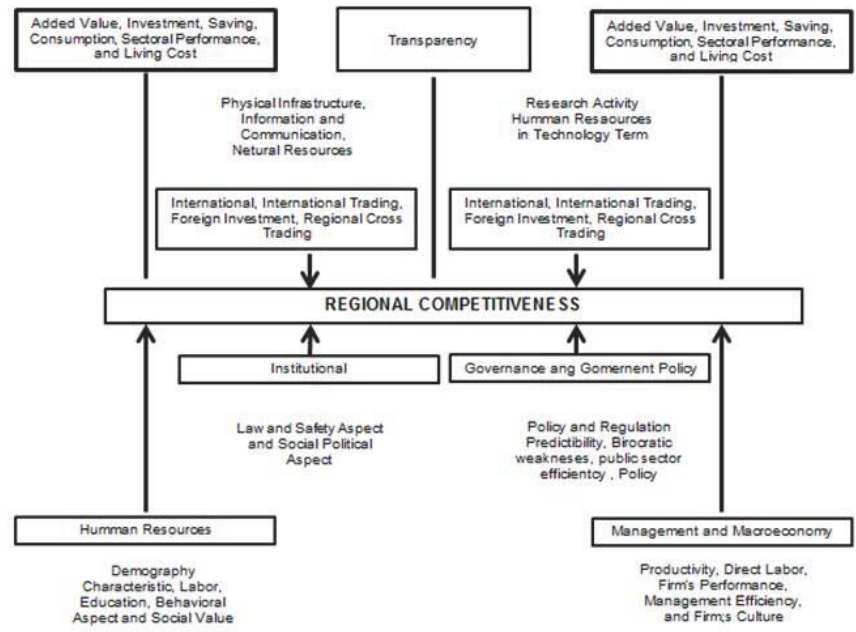

Figure 1: The Components Determining the Regional Competitiveness

Source: Abdullah (2002)

Based on the background of the above problems then, the discussion of this article can be systematically and appropriately targeted, especially in Malang District, and directed through the formulation of the problem as follows: how to determine the potential of local wisdom in favor of mapping the area of industry? How to determine the socio-cultural and economic zoning to form an industrial cluster? How the implementation of the results of the mapping of cultural and social economic zoning has to do with the spatial plan of the region in support of regional innovation system and creating regional competitiveness?

\section{Conceptual Framework}

Competitiveness of the regions by definition made the English Department of Trade and Industris the ability of an area in generating income and employment are high with fixed open to domestic and international competition. This definition contains the meaning of the existence of free competition the mondial requires an area increase professionalism and productivity of labor, in the standard product quality internationally, which in turn can increase the income of the region. Another opinion, namely the Centre for Urban and Regional Studies (CURDS) definition of regional competitiveness more looked at as a business sector or corporate capability on an area in a high revenue generation as well as the level of wealth is more evenly distributed to the population. A second opinion on the competitiveness of the area are General, not to expound on the components of the competitiveness of the region as well as the indicators more operational.

Therefore, in explaining the concept of regional competitiveness needs to be spelled out in more detail into the dimension of the concept of competitiveness up to empirical indicators. Based on studies conducted by Abdullah (2002) regional competitiveness concept and indicators determining the competitiveness of the regional economy conditions covering the area, conditions of free market economic system, financial system and financial kelmbagaan, the condition of infrastructure and natural resources, science and technology, human resources, institutional model, Governments and Government policy, management and macroeconomic conditions.

The macro economic condition the elaboration can be observed through the gross domestic product (GDP), saving the community, end consumption society, investment, and the rate of inflation, import export conditions, as well as bank interest. Based on the condition of the GRP a region early inclination direction can be detected the potential local wisdom through the order of priority of each sector from 9 (nine) sector which is often used as the reporting format of the GDP on the basis of the cash price without being influenced or GDP inflation rate on the basis of the prices in force. Then more specified into details of each sector into each industry or type of business group in one klui. For example, the hotel and 
restaurant trade sectors covering trade, hospitality areas and a restaurant. Based on the condition of GDP per sector will be known early potential area an condition that is helpful to elucidate further the potential of a region's flagship. Whereas, the area was analyzed by utilizing RIS or SIDa (Harmono, 2014; Harmono and Agency of Research and Development of Malang District, 2014).

Without zoning are supported by economy, ecology and social culture of the local people, it will be difficult in implementation, especially when going to do social conditions of intervention of the community through the implementation of technology, in a pattern of thinking and social conditions popular culture is not appropriate or gab with technological mindset, then it will happen a lot of constraints in the implementation. Therefore, adaptation penetration process technology with process adjustment behavior social culture must continuously performed, ranging from the dissemination of technology introduction, giving concrete evidence of the benefit of technology, training-skills training utilizing technology, to the distribution of network marketing product. The reality of the situation is often failure occurred, the results of good technology through research and development, but socio-cultural conditions of the mindset of the society was not yet ready (Research and Development Agency District of Malang, 2012; Harmono and Agency of Research and Development of Malang District, 2014).

Based on the framework of thought into zoning technology adaptation of economic social and cultural community as a regional innovation system implementation with reference to the format of the Agency Research and Technological Development (2012) or Badan Pengkajian dan Penerapan Teknologi (BPPT) the Republic of Indonesia about innovative policy framework strategic metrics strengthening RIS or SIDa customizations namely: regional innovation system, industrial cluster, technoprener, innovation network, and plan based theme (Memorandum of Undestanding between the Government of Malang with BPPT, 2012). Furthermore, this regional innovation system development refers to the direction of national development policy implementation that had been in the realm of Repelita (Five-Year Annual Plan) changed direction into development policies that give them freely to the autonomy of local governments. In this case, the direction of national development policy using the six corridor economic development through MP3EI and then synchronized with the regional innovation system in regional level provincial, county and city. In a schematic way it is depicted in Figure 2.

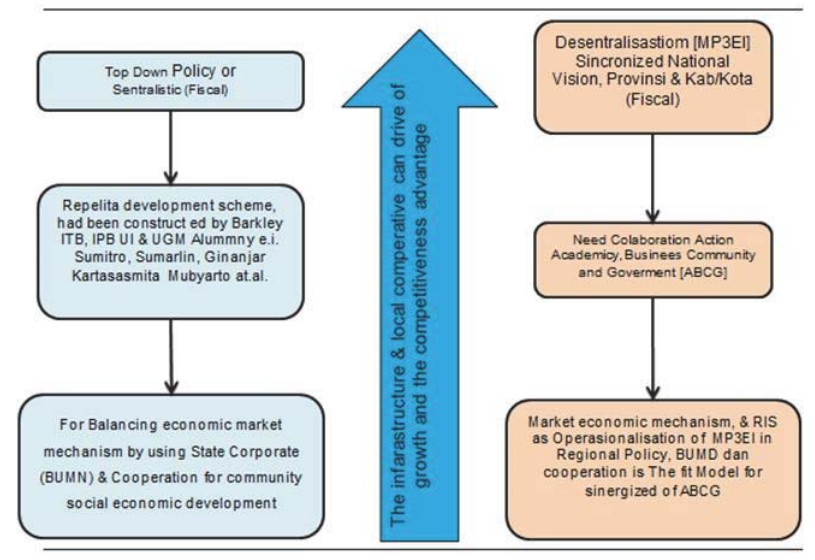

Figure 2: Framework for the implementation of Indonesia's development Policy

Source: Sintesis results of the direction of development policy Indonesia (Harmono: 2010).

\section{Research Methodes}

The design of this research is descriptive research designed as explanatory i.e. describing the production factors associated with development of the industrial park in Malang, then the network conditions of the market and institutional supporters associated with the condition of the spatial plan of the region based on the data in the secondary as well as primary data from the survey directly and through a questionnaire including Focus Group Discussion to complement the data ready basis of research data analysis.

Framework the identification of industrial zones in Malang using descriptive analysis framework through the 
explanatory variables are based on the conditions, the development of industrial type Spatial planning and territory or RTRW (Rencana Tata Ruang Wilayah / Spatial Plan) on each the unit area development or SWP (satuan wilayah pengembangan) District of Malang, Nine development sectors contained in the report, GDP, and the disparity area, public perception against the potential of industrial areas. In addition, it needs to be seen from the aspect of human resources, availability of raw materials, market conditions, as well as the laws and regulations that are binding as the basic stance of the area development in Malang primarily associated with the development of industry in the region to support the implementation of the program in Malang District.

Data analysis using a descriptive approach in the form of tables, graphs, frequency, trend, and images with attention to variability and heterogeneity of conditions and developments in the field, as well as consider various limitations that exist, both the substance of the field as well as methodological, equipped with an interactive approach (Miles \& Huberman, 1995). According to the interactive approach, the process activities can be classified into three things, namely: 1) the reduction of data or information, 2) presentation of data or information, and 3) draw conclusions or verification, which the three of them not always sequential, however, they simultaneously interacting.

\section{Research Result}

\subsection{Potentials In The District Of Malang}

Based on data conditions gross Regional Domestic Income on the basis of Constant Prices, the potential income can be observed through the Poor District of 9 sector development programme are contained in the GDP. As for the potential average starting in 2005 up to 2015 in the majority of the revenue potential of the agricultural sector contributed amounted to 30 percent and $18 \%$ processing industry and followed by public services and Government amounted to $13 \%$, and the subsequent order of financial leasing, transportation and communication, excavations and electricity and clean water is about $1 \%$. Thus, based on the gross revenue potential District of Malang many engaged in the agricultural sector and processing industry. Description in clear conditions of Malang District potentials can be shown through Figure 3.

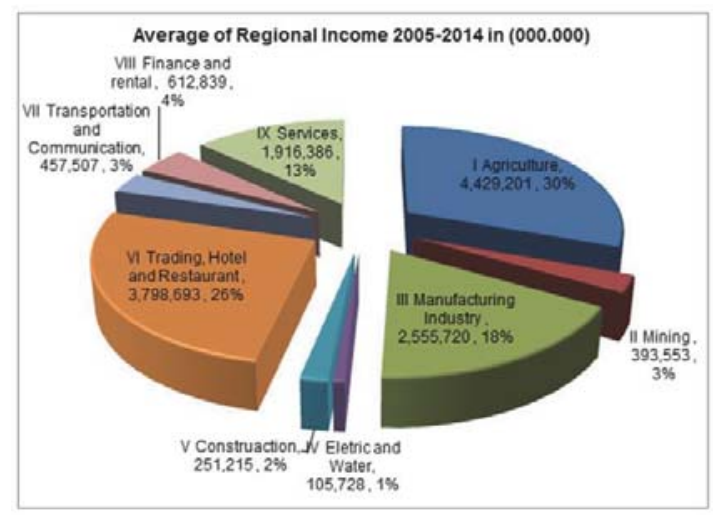

Figure 3: Gross Regional Income Potential average 2005-2014

Source: Central Bureau of Statistics Malang District (2015)

On the other hand, in terms of the growth rate of economic growth based on the income of Malang on each sector's development. District of Malang that have potential for agriculture and processing industry turned out to be the greatest growth rate of its economy is the sector of the building, then the processing industry in this industry is dominated by a lot of processed food and beverages and industrial raw materials for, e.g., processed smoking tobacco. Whereas the agricultural sector which is the biggest potential owned Malang instead most small growth in 2010 and a $4.13 \%$ increase in the year 2014 be 5.70\%. Other potentials of Malang with the Brantas River, and some dams for electricity generator, ranging from the Sengguruh Dam, the dam Selorejo Sutami potential as the main electricity supplier in East Java have a growth rate in the year 2010 amounted to 6 percent and the average decline. Thus the proper agriculture, electricity and 
clean water which is relatively better than other areas can become the pre-eminent regional competitiveness, in reality the growth rate was still relatively low compared to other development sectors including transport and communication, finance leasing.

Perhaps this power sector as companies are the state-owned, so that less affect regional revenue, even with the government's policy of using alternative energy Malang biogas and bio-electric energy renewable alternatives, thereby, reducing the acceptance of revenues from electricity. These conditions need to be examined further. Tertiary sector i.e. joyous trade hotels and restaurants had average 2005 - 2014 amounted to 6,12\% in 2014 rose to 5,70\%. This means that the marketing of the products in Malang good domestic and export trade has increased. Because as the tertiary sector this is one of the key success factors of increased economic growth, while supported by primary agriculture sector and secondary processing industry, then there is hope of increased economic growth of Malang area for the better. In detail the conditions of the economic growth rate in each sector development can be shown in Figure 4.

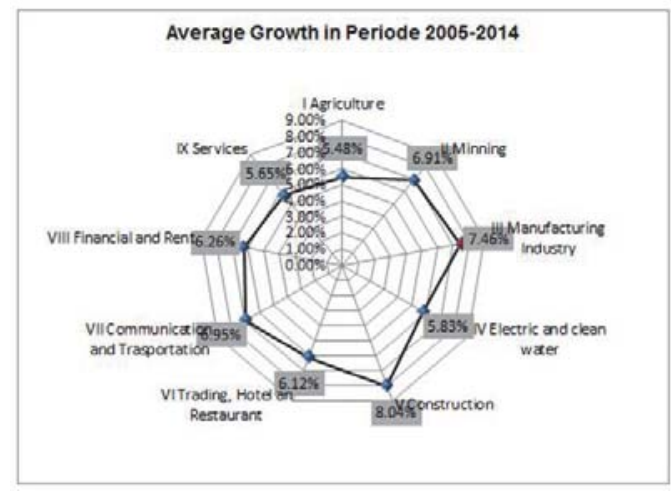

Figure 4: The Economic Growth of Malang 2005 - 2014

Source: Central Bureau of Statistics Malang District (2015)

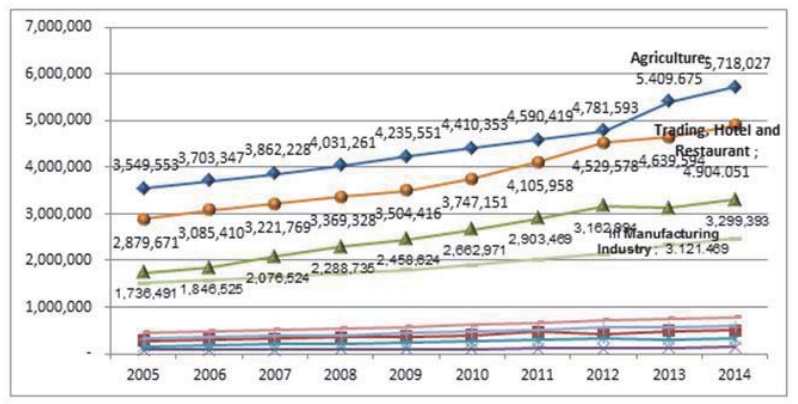

Figure 5: Processing Industry Sector in Malang period 2005-2014 (in millions)

Source: Central Bureau of Statistics Malang District (2015)

Economic growth rates in District Malang from period to period began in 2005 and ended the year 2014 is dominated by its main processing industry the processed food and beverage industry and the industry of processed tobacco results. Then the next sequence of chemical fertilizer and stuff from the rubber industry and other processed relatively small growth rates such as textiles and footwear, goods made of wood, cement and other non metallic minerals, paper and printed material and other items, which can be described in detail in Figure 5.

Based on the potential zoning and mapping the conditions of social-cultural community development corridor could be determined to be three zoning in Malang is beneficial for development policy strategy which simply can be shown through the image in Figure 6. 


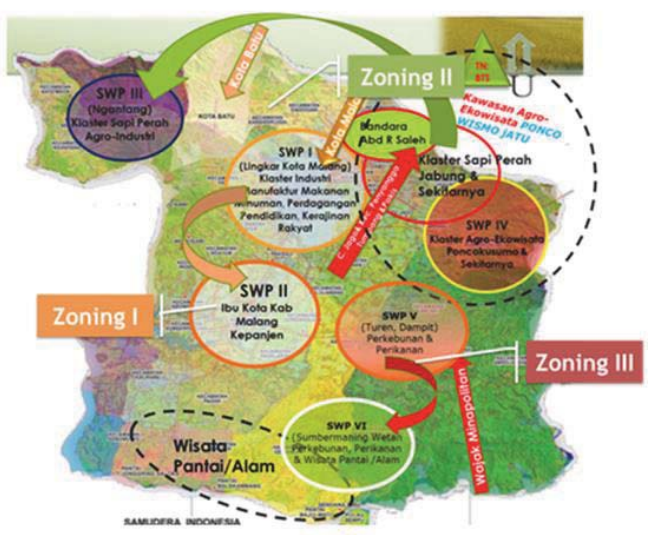

Figure 6: Zoning of Strategic Area of Malang Ditrict

The results of the mapping of areas of development are divided into strategic areas appropriate zoning potential similarities of each area can be simplified into three zoning district economic and socio-cultural characteristics of the conditions of the community. This can be made the determination of priority policy strategy development corridor in Malang. Existing conditions in line with East Java province Regional Plan and Development, which sets its surrounding area as a center of economic growth with potential as agropolitan. The results of this study relied upon the development of a prioritized strategic areas as implementation of SIDa Malang, commonly referred to as five bonded area, namely "Ponco-Wismo-Jatu" (Subdistrict: Poncokusumo, Wajak, Bromo, Jabung, and Tumpang) and Mt. Bromo as the principal. In schematic condition the RTRW East Java province can be shown in Figure 7. Mapping of socio-cultural-economic zoning Malang is in line with the determination of the MP3EI corridor is divided into six flagship centers corridor development programs appropriate to the national development potentials (The Ministry of Finance of the Republic of Indonesia, 2012).

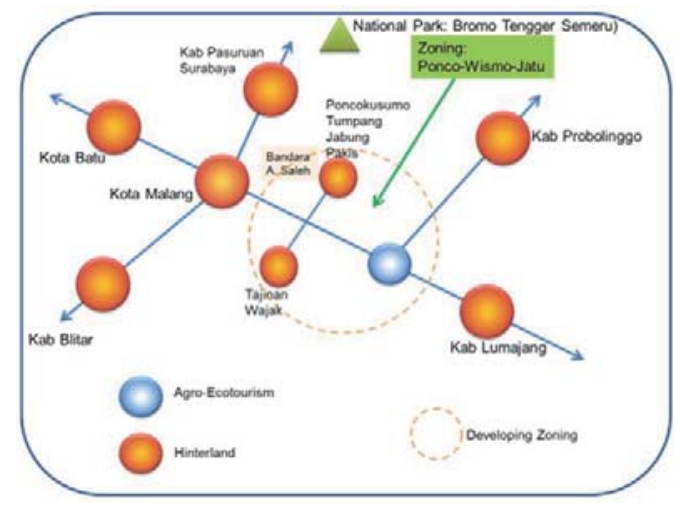

Figure 7: The Structure of East Java Province and Strategic Area and its surroundings

\subsection{Factors That Affect District Of Malang Industrial Area Supporting RIS}

As the basis for the development of the use of space, based on the results of a survey of the entire government apparatus Malang represented by departments related that in fact is the organizer of the Government knowing carefully against the potential and direction of development policies in Malang shows that, factors to be considered in the use of space and the development of an industrial area in general to six SWP in Malang there are four factors namely consists 
of: (1) Spatial factors in the region; (2) institutional factors and the human resource, (3) factors of comparative advantage, and (3) environmental factors. Some aspects related to the factor of spatial areas that must be considered was:

(1) Adherence to the limits of the region's agricultural and industrial area, that is to say in the development of industrial areas should pay attention to the limits of the policy area RTRW already outlined by observing the strategic value of the location of the region, the level of soil fertility, zoning and development business, with fixed aspect statutes of productive agricultural land area.

(2) Caution in enforcing licensing by observing the vast agricultural land.

(3) enforcement of regulations in the region in order to awake the security and preservation of the environment as well as the consideration of the economic value of the strategic value of an area.

(4) Considering the level of soil fertility, should the development of the industrial park don't get the area of farmland that is a potential flagship in Malang Regency, as well as one of the producers of agricultural products that is sustainable.

(5) Aspects of the coverage of the market, infrastructure and public facilities should be designed in an integrated before developing wild population density, which will give rise to problems of structuring space in the future. Therefore, the infrastructure setup must be able to anticipate the development of various aspects of up to tens of years in the future as well as the arrangement of public facilities like markets, hospitals, education and terminal areas and a business centre with appropriate attention to green open spaces, objects and tourist attraction that leads to the development of environmentally friendly area.

(6) Determination of the location of the market as market agro should consider economic growth centers are tailored to the agro-ecotourism so that the determination of the location of the market, it will impact on the development of agro-ecotourism in particular in the area of Ponco-Wismo-Jatu to connect with national parks Tengger-Bromo-Semeru is already known internationally. Through strategic infrastructure setup ranging from Surabaya, Singosari Temple towards to the airport Abdul Rahman Saleh, to the Jabung industrial centers as a dairy farm.

(7) The development of an industrial area that is environmentally and the availability of clean water. With the potential area of Malang to the East is surrounded by Mt. Bromo-Semeru, to the West there is a Mount Panderman, mount Arjuno, and to the South there is the mount Kawi, making these poor counties have a vast natural environment and potential as a buffer cities, primarily in terms of the preservation of the natural environment and the provision of mountain spring water.

\section{Discussion}

The conceptual framework of implementation Regional Inovation System (RIS) has developing in Indonesia is adobt a Micheal Porter's Diamond Strategy Model (Porter, 1998; Porter, 2000). Herewith this contects it's just adopt the concept not to adept on the situation in fullfilment asummtion of the model. Therefore, in the some region can't optimize to implement RIS in Indonesia. Acording to experts give the critique on Dimond Strategy Model will fit do that when the environment is supporting the model like: vendors, producers as cluster, and market is well prepare to optimized the operation of firms unless the model will not optimal in operasional the clusters (National Development Agency, 2000). Therefore, based on the finding of the research, in implementing of Micheal Porter's Model must be adepted in and identified of the potential of each region with zoning strategy. Commonly in developing countries included in Indonesia need adjust to charactersitic market (Mulyadi, 2013), comperative advanted in materials, labours intensive and supporting of technology in integrated system to optimize the Regional Inovation System (RIS or SIDa). The elaboration of the potential area in more detail the third strategy zoning the Malang business can be seen as:

Business Zoning Strategy I (BZS) use of space that have the same characteristics of the development potential of the fore SWP I (Circumference of Malang) and SWP II (capital of Kepanjen) that have the potential of winning as the hotel and restaurant trade, education and health, industrial, processed food and beverages, as well as potentially as an informal sector development, can be relied upon Business Zoning Strategy I, primarily around the circumference of the city can be utilized as an industrial area.

Business Zoning Strategy II use of space that has the characteristics of a potential region associated with the potential of agro-ecotourism which has potential as a producer of agricultural food crops, vegetable and fruit, tourism, dairy farm, and agro industries located in the SWP III (Ngantang and surroundings) and the SWP IV (Tumpang/PoncoWismo-Jatu) Poncokusumo Wajak, Mt Bromo Tengger Semeru National Park, Jabung and currently being RIS Malang County Center development. Both the food and agro-industrial centers of the determination of the market of agro-tourism, as well as roads connecting to objects and tourist attraction in integrated and environmentally sustainable. 
Business Zoning Strategy III utilization of the space could potentially capture fisheries and areas as farming, forestry, and natural attractions. Sub area of development that have such characteristics sits on SWP V (Turen Dampit and surroundings) and the SWP VI (Sumbermaning Wetan village and surrounding areas). Both the SWP this potentially as a producer of rubber plantations, coffee, cloves, timber forest products, and potentially as a producer of fish farming, complete processing industry, market, there's been a marine vocational education, and the fish auction, dock/harbor, beaches/nature. Thus the use of space is more directed at infrastructure, plantations, fisheries, and natural attractions. Including adaptations against RTRW, preferably directed at potential.

Based on the three basic strategies for dealing with the problems of the development strategy of development policies in Malang such extensive and complex it can become more and more integrated and right on target. The discovery of this strategy is one of the key research findings, which can be relied upon the determination of the direction of policy development programs of RIS in Malang District.

The interconnectedness of the mapping results in support of the implementation of the industrial area. Based on the probe of the potentialities of local wisdom's flagship owned Malang, as well as the industrial area mapping strategy, then position the results of this study to implementation on strengthening regional innovation systems in Malang is: First, a potential comparative advantage can be the basis of the determination of the industrial cluster core themes that would be lifted on RIS. The second, area of RIS implementation be right on target with attention to the eyes of the supply chain, and then observe the spatial plan of the region which puts hospitality towards preservation of the environment as well as the strategic position of the region can be determined precisely target and integrated and can determine the order of priority development in improving the competitiveness of the region.

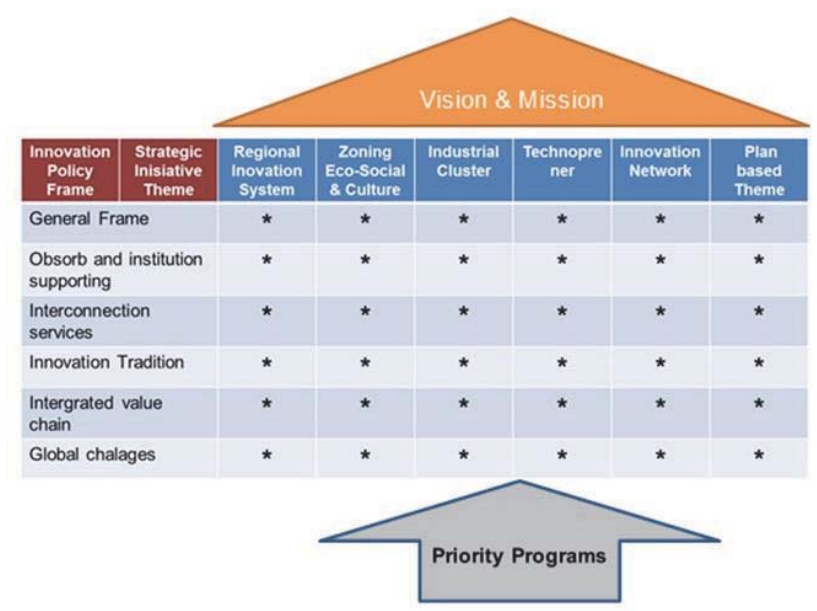

Figure 8: The matrix reinforcement of regional innovation System Customizations by adding the dimension of Economicsocio-cultural Region of zoning as the Determinant Area implementation of RIS

Implementation of the program in Malang has been supported by the determination of "Zoning of economic-socio-culture" containing the meaning that, in a sense of economic zoning empowerment and local eco ecological conservation notice as the natural environment, as well as social culture is one of the key success factors for the implementation of the program. When we incorporate technology to increase the added value of such a product, if the economical condition of the socio-cultural community not ready then it happened thus extravagance and rejection, which ultimately was a failure. Therefore, based on the results of this research then, Zoning of Economic-Social-Culture became one of the key requirement in the development of RIS or SIDa. Thus the pillars of the framework of the strengthening of the program in Malang as described in Figure 8.

\section{Conclusions}

First, Based on the identification of the potential of each region in the territory of the region until the development of zoning I-VI can be simplified into three zoning development that is socio-cultural-economic Zoning I is circumference of 
the capital city of Malang fits as the industrial area of processed food and beverages, small-medium enterprises, education and health, trade, hotels and restaurants and financial services, banking and non-bank. With the cultural characteristics of urban as the community industry, trade and services. Socio-cultural-economic zoning II is the development of III and the surrounding area and Ngantang region surrounding that match and developed as agropolitan, agricultural societies with culture. Zoning of economic-socio-cultural development of the region III is the V Turen, Dampit Sumbermanjing Wetan VI and WP and the surrounding area developed as suitable plantation, minapolitan, mining, crafts people, and shore excursions. The characteristics of the culture of the community forestry, fisheries, and industry folk crafts.

Second, Based on the analysis of main factors found four factors that can be used as guidelines for the development of the region include: (1) environmental factors, (2) institutional factors and human resource development, this region need to consider potential human resources and cultural society, (3) comparative advantage factors in the areas of agribusiness, crafts people, and has the potential of Malang as agropolitan, and (4) socio-cultural and environmental factors of nature.

\section{Acknowledgement}

The study was sponsored by the Agency of Research and Development of Malang District-East Java

\section{References}

Abdullah, Pitter, 2002, The Regional Competitiveness: Concept and Measurement in Indonesia, First Edition, Education and study center "Central Banking" Bank of Indonesia, in collaboration with BPFE Jogyakarta.

Central Bureau of Statistics Malang District, 2013, Malang Regency in Figures, Bureau of Statistics Malang. Poor

Fatchan. Ach. 2004. Application of Technology "Panca Usaha Tani" At Community Based Wetland Pesantren, Journal of Mathematics and Teaching. Vol I / 1 July 2004 (pages 40-58). State University of Malang.

Harmono, 2010, Study of the importance of the industrial area to Increased Investment in Malaysia, in collaboration with the Research and Malang.

Harmono, 2014, Mapping General Plan Investment Malang, in Colaboration with Bappeda Malang

Harmono and Agency of Research and Development of Malang District. 2014. Development of Regional Innovation Systems "PonchoWismo-Jatu", Malang, Research and Development of Malang District

Kazuhiza, Matsui, 2005, The Movement of One Village One Product (OVOP): An attempt of Regional Revitalization in Japan, the Regional Development Policy Projects for Local Governments (RDPLG) colaborate with JICA and DG Regional Development, Home Affairs, Jakarta.

Kompas, 2014, President-elect Joko Widodo hinted could not continue the program of Master Plan for the Acceleration and Expansion of Indonesian Economic Development (MP3EI). Jakarta, 5 September 2014.

Memorandum of Undestanding between the Government of Malang with BPPT dated January 17, 2012 Number: 119/351/421 022/2012 and No. 05 / KB / BPPT-regency. Malang / 01/2012 on the Assessment, Implementation and Corrections Technology to Support Regional Development Malang East Java Province.

Ministry of Research and Technology, 2012, Joint Regulation of the Minister of State for Research and Technology and the Minister of the Interior No. 03 of 2012 and No. 36 of 2012 on Strengthening Regional Innovation System that is currently taking place in various areas.

Mulyadi, Smith (2013), Improving Competitiveness Through the Regional Industrial Development Industrial Growth Centres, the Directorate General for Development of Industrial Zoning, Presented at the Meeting of the Ministry of Industry Jakarta, May 22, 2013,pp.5-20.

Miles, Matthew B and A Michael Huberman, 1995, An Expanded Sourrce Book: Qualitative Data Analysis, Sage Publications, London.

Malang Regency Regulation No. 2-2011 Concerning, Medium Term Development Plan Malang Regency Year 2010-2015.

National Development Agency, 2000, The Cluster Industry to Regional Economic Helpless High Competitiveness Development, Directorate of Special Areas and Disadvantaged, Jakarta.

Porter, ME, 1998, 'Clusters and the new economics of competition', Harvard Business Review, 7 (6), pp6-15.

Porter, ME, 2000, 'Location, Competition and Economic Development: Local Cluster in a Global Economy', Economic Development Quarterly, 14 (1), pp7-20.

Research and Development Agency District of Malang, 2012, The Roadmap for Strengthening Regional Innovation Systems Malang, Malang Regency Government Cooperation with BPPT.

The Ministry of Finance of the Republic of Indonesia, 2012. MP3EI. Six-corridor of Economic Development of Indonesia, the Ministry of Finance. go.id. 